\title{
Struktutr Komunitas Ikan dan Tutupan Karang di Area Biorock Desa Pemuteran, Buleleng, Bali
}

\author{
Febriyanto Arifin ${ }^{a *}$, I Gusti Ngurah Putra Dirgayusa a, Elok Faiqoh a \\ a Program Studi Ilmu Kelautan, Fakultas Kelautan dan Perikanan, Kampus UNUD Bukit Jimbaran, Bali 80361, Indonesia \\ * Penulis koresponden. Tel.: +62-82-237-071-188 \\ Alamat e-mail: febriyanto.arifin@yahoo.com
}

Diterima (received) 19 Desember 2016; disetujui (accepted) 6 Februari 2017; tersedia secara online (available online) 7 Februari 2017

\begin{abstract}
Biorock is new method of coral reef rehabilitation. Today, the structure Biorock been made in various shapes and sizes. Therefore, assessment of reef fish communities and coral cover on the artificial reef Biorock of different sizes are needed as a as the basic information and the utilization of the results of the conservation area. From this research, it is known that the six Biorock structure obtained reef fish composition consisting of 18 Family and 45 fish species and abundance of total 2065 individuals. In accordance with the classification of diversity index Shannon - wiener all sizes Biorock the research object falls into the range of values diversity moderately $1.57-2.95$. The results of the uniformity index show that in every size Biorock has equal distribution of species. From the results of the dominance of index calculation (C) is included in the low category. Where in any size Biorock not happen domination by a single species. In all sizes Biorock have value mengindikasinkan that coral is in good shape. The highest coral cover in sequence contained in the structure of Small-sized Biorock 1, 1 medium, 2 Large, 2 Small, 2 Medium, and 1 Large. From analysis using Bray-Curtis similarity index gained 2 groups Biorock structures that have similar types of fish encountered. The first group is the first Large-sized Biorock structure, Large 2, and the medium 1. The second group is the structure of Small-sized Biorock 1, 2 medium and 2 Small.
\end{abstract}

Keywords: Biorock; community structure,coral cover; Bray - Curtis Similarity Index

\begin{abstract}
Abstrak
Biorock merupakan metode baru dalam perehabilitasian terumbu karang. Saat ini struktur Biorock telah dibuat dalam berbagai bentuk dan ukuran. Oleh karena itu, pengkajian tentang komunitas ikan karang dan tutupan karang pada terumbu buatan Biorock dari berbagai ukuran tersebut perlu dilakukan sebagai dasar dan informasi hasil konservasi dan pemanfaatan wilayah. Dari penelitian yang dilakukan diketahui bahwa pada enam Struktur Biorock didapatkan komposisi ikan karang yang terdiri dari 18 Famili dan 45 Spesies dan kelimpahan total ikan 2065 individu. Sesuai dengan klasifikasi indeks keanekaragaman Shannon - wiener semua ukuran Biorock tergolong dalam keanekaragaman sedang. Indeks keseragaman setiap ukuran Biorock memiliki nilai keseragaman komunitas besar. indeks dominasi (C) dalam kategori rendah. Pada semua ukuran Biorock menunjukkan bahwa karang dalam kondisi yang baik. Tutupan karang tertinggi secara berurutan terdapat pada struktur Biorock berukuran Kecil 1, medium 1, Besar 2, Kecil 2, medium 2, Besar 1. Dari analisis menggunakan indeks kesamaan Bray Curtis didapatkan 3 kelompok struktur Biorock yang memiliki kesamaan jenis ikan yang ditemui. Kelompok pertama adalah struktur Biorock berukuran Kecil 1, Kecil 2, medium 2. Kelompok kedua yaitu struktur Biorock berukuran medium 1 dan Besar 2. Dan kelompok ketiga yaitu struktur Biorock Besar 1 yang memiliki indeks kesamaan terendah dibandingkan dengan struktur Biorock yang lain.
\end{abstract}

Kata Kunci: Biorock; struktur komunitas ikan; tutupan karang; Indeks Kesamaan Bray-Curtis

\section{Pendahuluan}

Indonesia termasuk dalam wilayah "Coral Triangle" dimana wilayah tersebut memiliki tingkat keanekaragaman terumbu karang yang tinggi (Veron et al., 2009). Terumbu karang adalah organisme laut yang tinggal di wilayah 
bertemperatur hangat, kedalaman dangkal dan cerah di seluruh wilayah dunia. Hal senada juga diungkapkan oleh Carpenter et al. (2008) yang menyatakan bahwa dua pertiga ikan karang di dunia diyakini mendiami daerah segitiga karang dunia dimana Indonesia termasuk didalam wilayah tersebut.

Aktivitas manusia yang semakin tinggi di daerah pesisir merupakan tekanan terhadap ekosistem laut khususnya ekosistem terumbu karang (McLeod et al., 2010). Tekanan yang diberikan oleh lingkungannya dapat berupa pencemaran dari daratan, praktek perikanan yang merusak dan pengambilan terumbu karang ilegal. Terumbu karang di wilayah Indonesia $23 \%$ di Indonesia Bagian Barat dan $45 \%$ di Indonesia Bagian Timur berada dalam kondisi baik, berarti 60\%-70\% berada dalam kondisi rusak (Maddupa et al., 2007). Pemerintah dan masyarakat harus menginisiasi cara pengelolaan yang lain, seperti perbaikan habitat secara buatan, salah satunya adalah pembuatan terumbu buatan.

Perairan desa Pemuteran terletak di sebelah barat Kabupaten Buleleng, Bali. Kondisi terumbu karang di perairan Pemuteran sekarang ini jauh berbeda dengan kondisi beberapa tahun yang lalu (Dunning, 2015). Pada tahun 2000 rehabilitasi terumbu karang dimulai dan dipelopori pertama kali oleh Tom Goreau dan Wolf Hilbertz berupa terumbu buatan Biorock(Bottema and Bush, 2012). Terumbu buatan Biorock merupakan proses alami pembentukan padatan mineral pada kerangka besi yang diberikan listrik tegangan rendah melalui elektroda, mineral yang dihasilkan adalah kalsium karbonat dan magnesium hidroksida. Menurut Harris (2009) dan Lissa (2013) selain sebagai restorasi ekosistem juga dapat menjadi pelindung erosi pesisir.

Sejak diletakkan pertama kali belum dilakukan kajian dan monitoring tentang struktur komunitas ikan karang dan tutupan terumbu karang yang berada di daerah Biorock. Dari berbagai ukuran yang ada perlu diketahui kepadatan dan keanekaragaman ikan yang melakukan aktivitas disana dan tutupan terumbu karang pada ukuran Biorock besar (Besar), sedang (Medium) dan kecil (Kecil) Oleh karena itu, pengkajian yang mendalam tentang struktur komunitas ikan karang dan tutupan terumbu karang terumbu buatan Biorock yang diletakkan di perairan Pemuteran perlu dilakukan sebagai dasar dan informasi hasil konservasi dan pemanfaatan wilayah, yang nantinya dapat dilakukan di daerah lain di Indonesia.

\section{Metode Penelitian}

\subsection{Waktu dan Tempat}

Penelitian ini dilaksanakan pada bulan Februari hingga Mei tahun 2016. Penelitian ini meliputi survei lokasi penelitian (penentuan struktur Biorock) yang akan dijadikan sampel data. Pengambilan data komposisi ikan, kelimpahan ikan dan struktur komunitas ikan. Penelitian dilakukan di area Biorock Desa Pemuteran, Buleleng, Bali.

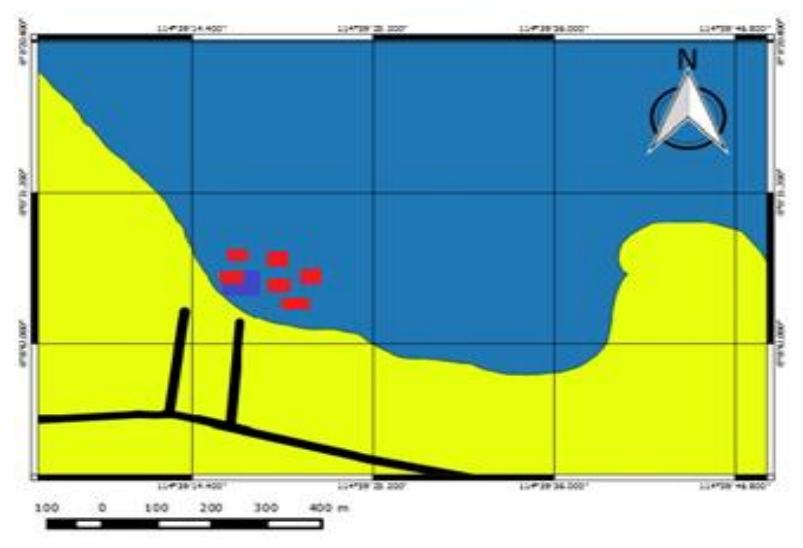

Gambar 1. Peta Lokasi Penelitian, titik merah mengindikasikan lokasi Biorock.

\subsection{Peralatan}

Peralatan yang digunakan dalam menunjang pengukuran biota karang dan ikan dalam penelitian ini dapat dilihat pada Tabel 1.

Tabel 1. Peralatan

\begin{tabular}{|c|c|}
\hline Alat & Kegunaan \\
\hline SCUBA diving & Menyelam \\
\hline Roll meter & Membuat garis transek \\
\hline $\begin{array}{l}\text { Sabak bawah air dan } \\
\text { pensil }\end{array}$ & Mencatat data di dalam air \\
\hline Kamera bawah air & $\begin{array}{l}\text { Mendokumentasikan } \\
\text { kegiatan }\end{array}$ \\
\hline GPS & Menentukan koordinat lokasi \\
\hline Buku identifikasi ikan & $\begin{array}{l}\text { Mengidentifikasi data ikan } \\
\text { yang diperoleh }\end{array}$ \\
\hline Ms. Word & Penulisan laporan \\
\hline Ms. Excel & $\begin{array}{l}\text { Membuat grafik dan } \\
\text { perhitungan struktur } \\
\text { komunitas }\end{array}$ \\
\hline MVSP(multi-Variant & Menghitung indeks Bray- \\
\hline Statistical Package) & $\begin{array}{l}\text { Curtis dan membuat } \\
\text { dendogram. }\end{array}$ \\
\hline
\end{tabular}




\subsection{Metode Pengumpulan Data}

Pengamatan diambil pada enam titik di daerah Biorok Pemuteran Kabupaten Buleleng. Pengambilan data berdasarkan tiga bentuk terumbu karang buatan yaitu ukuran besar ukuran $>5 \mathrm{~m}^{2}$, sedang $3 \mathrm{~m}^{2} \geq 5 \mathrm{~m}^{2}$ dan kecil $<3 \mathrm{~m}^{2}$. Data pengamatan yang diambil adalah data tutupan karang yang menempel di terumbu karang buatan, data komunitas ikan yang hadir di terumbu karang buatan.

\subsubsection{Metode Pengamatan tutupan karang}

Metode yang digunakan untuk pengamatan tutupan terumbu karang adalah metode Line Intercept Transect (LIT). Transek diletakkan diatas terumbu buatan Biorock. Tipe substrat dasar dicatat dengan menggunakan bentuk hidup (life form).

\subsubsection{Metode Pengamatan Komunitas Ikan}

Pengambilan data ikan karang spesies target menggunakan metode sensus visual, dimana di setiap struktur Biorock diletakkan transek berukuran $5 \times 5$ meter sebagai patokan dalam pengambilan data. Data yang diperoleh adalah jumlah spesies dan jumlah individu masingmasing spesies ikan.

\subsection{Analisa Data}

\subsubsection{Kelimpahan Ikan karang}

Kelimpahan ikan karang dihitung dengan menggunakan persamaan dibawah ini (English et al., 1994) :

$N=\frac{n i}{A}$

dimana $N$ adalah kelimpahan ikan (ind $\left./ \mathrm{m}^{2}\right) ; n i$ adalah Jumlah individu ke-I; dan $A$ adalah luasan area $\left(\mathrm{m}^{2}\right)$.

\subsubsection{Persentase Penutupan Karang}

Persentase penutupan karang hidup dihitung dengan menggunakan persamaan dibawah ini (UNEP, 1993):

$n i=\frac{l i}{L} \times 100 \%$ dimana $n i$ adalah persentase penutupan karang hidup life form ke-I; li adalah panjang total life form karang ke-I; dan $L$ adalah panjang transek garis.

Data persentase penutupan karang hidup yang diperoleh dikategorikan berdasarkan Gomez dan Yap (1988) dapat dilihat pada Tabel 2 dibawah ini:

Tabel 2. Kategori tutupan karang

\begin{tabular}{cc}
\hline $\begin{array}{c}\text { Persentase } \\
\text { Penutupan }\end{array}$ & Kriteria Penilaian \\
\hline $0-24,9$ & Buruk \\
$25-49,9$ & Sedang \\
$50-74,9$ & Baik \\
$75-100$ & Sangat Baik \\
\hline
\end{tabular}

\subsubsection{Indeks Mortalitas Karang}

Indeks morrtalitas (IM) karang menunjukkan adalah nilai untuk menduga kondisi dari tutupan terumbu karang. Adapun rumus indeks mortalitas yaitu:

$\mathrm{IM}=\frac{\text { Persen } \text { Karang Mati }}{\text { Persen karang hidup }+ \text { Persen } \text { karang mati }}$

Indeks mortalitas memiliki kisaran nilai antara 0 - 1 . Dengan kriteria jika nilai indeks mortalitas mendekati angka 0 maka rasio kematian karang kecil dan kesehatan terumbu karang tinggi. Sedangkan, nilai indek mortalitas karang mendekati angka 1 maka rasio kematian karang besar dan kesehatan karang rendah.

\subsubsection{Indeks ekologi}

Analisis indeks ekologi terdiri dari indeks keanekaragaman $\left(\mathrm{H}^{\prime}\right)$, indeks keseragaman (E) dan indeks dominansi (C) digunakan untuk mengetahui gambaran kondisi struktur komunitas karang dan ikan pada setiap stasiun pengamatan.

a. Indeks keanekaragaman

Indek keanekaragaman dapat menunjukkan keseimbangankeanekaragaman individu dalam tiap jenis, indek ini dapat dihitung dengan persamaan (Odum, 1998):

$H^{\prime}=-\sum_{i=1}^{n} p i \ln p i$

$H^{\prime}$ adalah indeks keanekaragaman ShannonWiener; $P i$ adalah ni/N (N : Jumlah total individu); $n i$ adalah jumlah individu genus ke-I. dimana bila 
$H^{\prime}<1$ dikategorikan sebagai keanekaragaman rendah; bila $H^{\prime} \geq 1$ dan $<3$ dikategorikan sebagai keanekaragaman sedang; dan bila $H^{\prime} \geq 3$ dikategorikan sebagai keanekaragaman tinggi.

b. Indeks keseragaman

Keseragaman jenis menunjukkan seberapa besar nilai kesamaan jumlah individu antar jenis pada suatu komunitas. Nilai dari indeks keseragaman dapat digunakan sebagai indikator dari ada tidaknya pendominasian oleh jenis tertentu pada suatu komunitas. Nilai indeks keseragaman dapat diformulasikan sebagai berikut :

$E=\frac{H^{\prime}}{H \max }$

dimana $E$ adalah indeks keseragaman (0-1); $H^{\prime} \max$ adalah nilai keseragaman maksimum $=$ Ln $S$; dan $S$ adalahjumlah taksa.

Nilai E berkisar antara 0,0 - 1,0 dengan kriteria jika nilai E mendekati 0,0 keseragaman komunitas ikan semakin kecil, ada kecenderungan terjadi dominasi oleh jenis-jenis tertentu, tetapi jika nilai $\mathrm{E}$ mendekati 1,0 maka keseragaman komunitas akan semakin besar yang berarti sebaran jumlah individu species sama (Odum 1998).

c. Indeks dominasi

Penghitungan indeks dominansi digunakan untuk melihat adanya dominansi, persamaan yang digunakan sebagai berikut:

$C=\sum(n i / N)^{2}$
$C$ adalah indeks dominasi simpson (0-1). Jika nilai C mendekati 0,0 maka komunitas yang diamati tidak ada species yang secara ekstrim mendominasi species lainnya. Hal ini menunjukkan kondisi struktur komunitas dalam keadaan stabil, tetapi bila $C$ mendekati nilai 1,0 maka didalam struktur komunitas dijumpai ada genus yang mendominasi genus lainnya.

\subsubsection{Indeks Kesamaan Bray-Curtis}

Kesamaan antar ukuran struktur Biorock dapat dianalisis dengan indeks Bray-Curtis dengan menggunakan software Multi-Variate Statistical Package (MVSP). Adapun rumus indeks kesamaan Bray-Curtis (Bray and Curtis 1975 dalam Somerfield 2008) yaitu:

$S_{\mathrm{jk}}=100\left(1-\frac{\sum\left|Y_{i j}-Y_{i k}\right|}{\sum\left(Y_{i j}+Y_{i k}\right)}\right)$

dimana $S_{j k}$ adalah indeks kesamaan antara contoh $\mathrm{j}$ dan $\mathrm{k}$ dalam persen; $Y_{\mathrm{ij}}$ adalah jumlah spesies ke I dalam kolom j; dan $Y_{i k}=J u m l a h$ spesies ke I dalam kolom k.

\section{Hasil dan Pembahasan}

\subsection{Komposisi ikan}

Dari penelitian yang sudah dilakukan pada 6 Struktur Biorock didapatkan komposisi ikan karang yang terdiri dari 18 Famili dan 45 Spesies dan kelimpahan total ikan 2065 individu. Ikan yang paling banyak ditemui secara berurutan dari famili

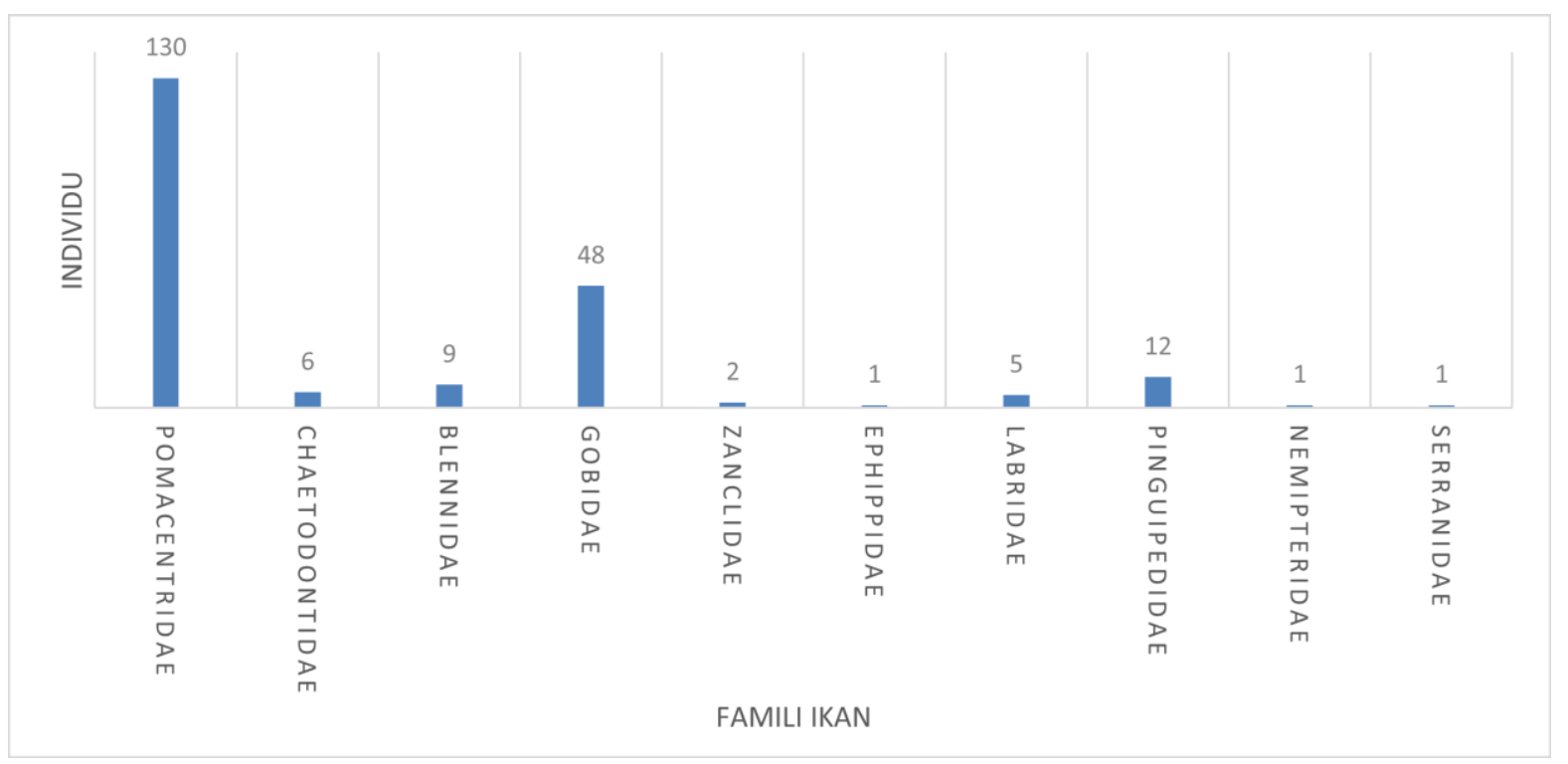

Gambar 2. Komposisi Jenis Ikan pada struktur Biorock kecil 


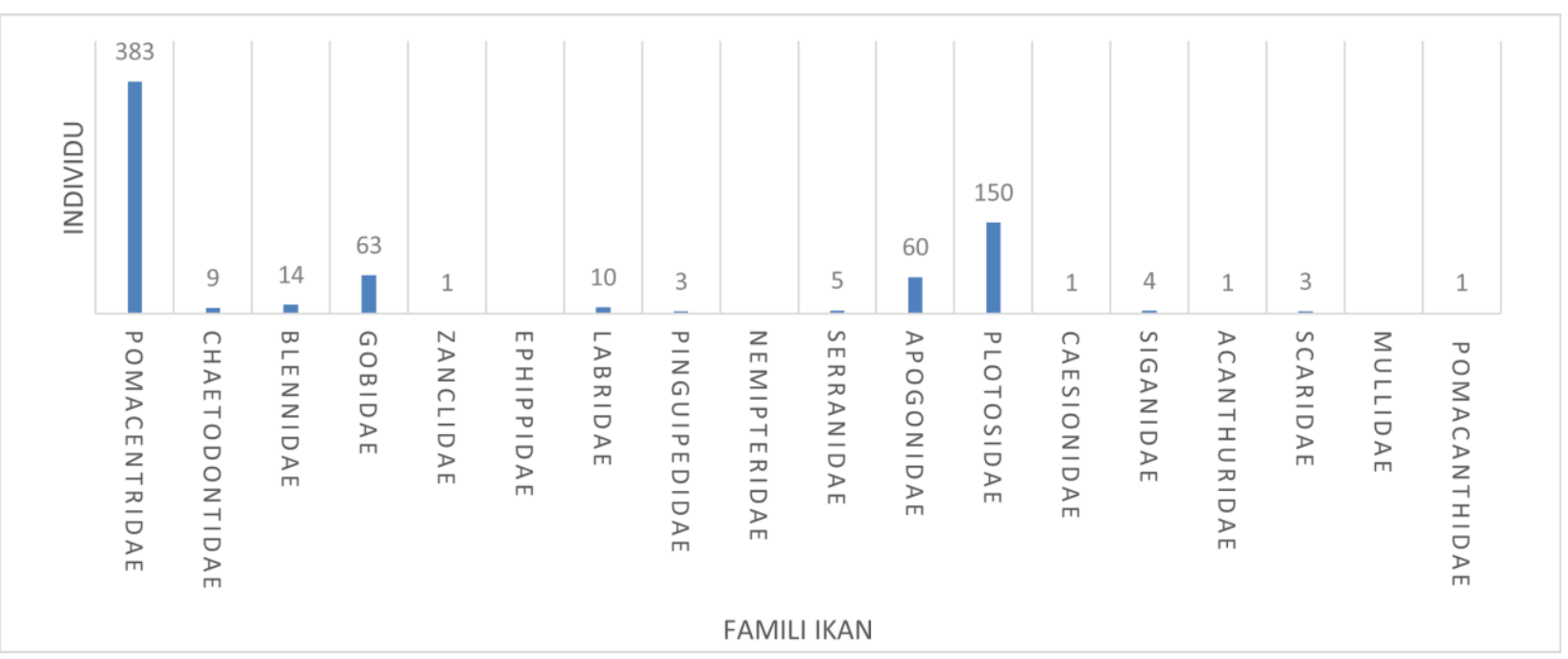

Gambar 3. Komposisi Jenis Ikan struktur Biorock medium

Pomancentridae sejumlah 1170 individu; Apogonidae 493 individu; Plotosidae 151 individu; Gobidae 112 individu; Labridae 34 individu; Blennidae 31 individu; Chaetodontidae 20 individu; Pinguipidae 15 individu; Serranidae 8 individu; siganidae 7 individu; Ephippidae 6 individu; Zanclidae dan Achanturidae 4 individu; Scaridae dan Nemipteridae 3 individu; Mullidae 2 individu; Caesionidae dan Pomacanthidae 1 individu. Total ikan yang ditemukan pada masing - masing ukuran struktur Biorock yaitu : Kecil 1138 individu, Kecil 277 individu, medium 1534 individu, medium 2173 individu, Besar 1557 individu dan Besar 2585 individu. Diagram komposisi jenis ikan pada setiap ukuran Biororck dapat dilihat pada Gambar 2 sampai Gambar 4. Famili Pomacentridae merupakan ikan yang paling banyak ditemui dan hidup berasosiasi dengan terumbu karang (Sugianti dan Mujiyanto, 2013).

Dari 18 famili yang ditemukan, setiap ukuran struktur Biorock memiliki sebaran yang berbeda beda. Struktur Biorock kecil ditemukan 10 famili dari 18 famili ikan yang ditemukan. Selain itu, berdasarkan peranannya 10 famili ini terdiri dari 1 famili ikan indikator yaitu famili Chaetodontidae, 2 famili ikan target yaitu famili Labridae dan Serranidae serta 7 famili ikan mayor. Struktur Biorockk medium terdapat 15 famili ikan yang terdiri dari 1 famili Chaetodontidae sebagai ikan indikator, 4 famili ikan target (Labridae, Serranidae, Siganidae, Acanthuridae) dan 11 famili ikan mayor.

Struktur Biorockk berukuran Besar terdapat 14 famili ikan yang terdiri dari 1 famili
Chaetodontidae sebagai ikan indikator, 5 famili ikan target (Labridae, Serranidae, Siganidae, Acanthuridae dan Mullidae) dan 8 famili ikan mayor. Ikan target merupakan ikan yang memiliki nilai ekonomis. Dilihat dari komposisi jenis ikan pada setiap ukuran Biorock, ikan target banyak ditemukan pada struktur Biorock Besar. Hasil ini dapat mengindikasikan bahwa ukuran struktur Biorock yang lebih besar lebih di sukai oleh ikan ikan target sebagai tempat mencari makan ataupun berlindung.

Dari data seberan famili ikan, paling banyak ditemukan adalah ikan dari famili Pomacentridae Chromis viridis sebanyak 362 individu; Pomancentrus moluccensis sebanyak 321 individu; Amblyglyphidodon curacao sebanyak 116 individu; Amblyglyphidodon batunai sebanyak 107 individu; Dascyllus reticulatus sebanyak 66 individu serta beberapa spesies dengan kisaran kelimpahan 2 50 individu. Pada umumnya ikan jenis ini memiliki ukuran yang relatif kecil dan cenderung hidup dan berlindung di karang bercabang (Rondonuwu dkk., 2013). Dari data tutupan terumbu karang dapat dilihat bahwa tutupan karang hidup dengan bentuk Acropora Branching dan Coral Branching banyak ditemui pada struktur Biorock.

\subsection{Kelimpahan Ikan}

Kelimpahan ikan dapat dilihat pada Gambar 5. Kelimpahan ikan tertinggi hingga terendah secara berurutan terdapat pada struktur Biorock Besar 2 dengan nilai 23.4 individu/ $/ \mathrm{m}^{2}$, struktutur Biorock Besar 122.28 individu $/ \mathrm{m}^{2}$, struktutur Biorock 


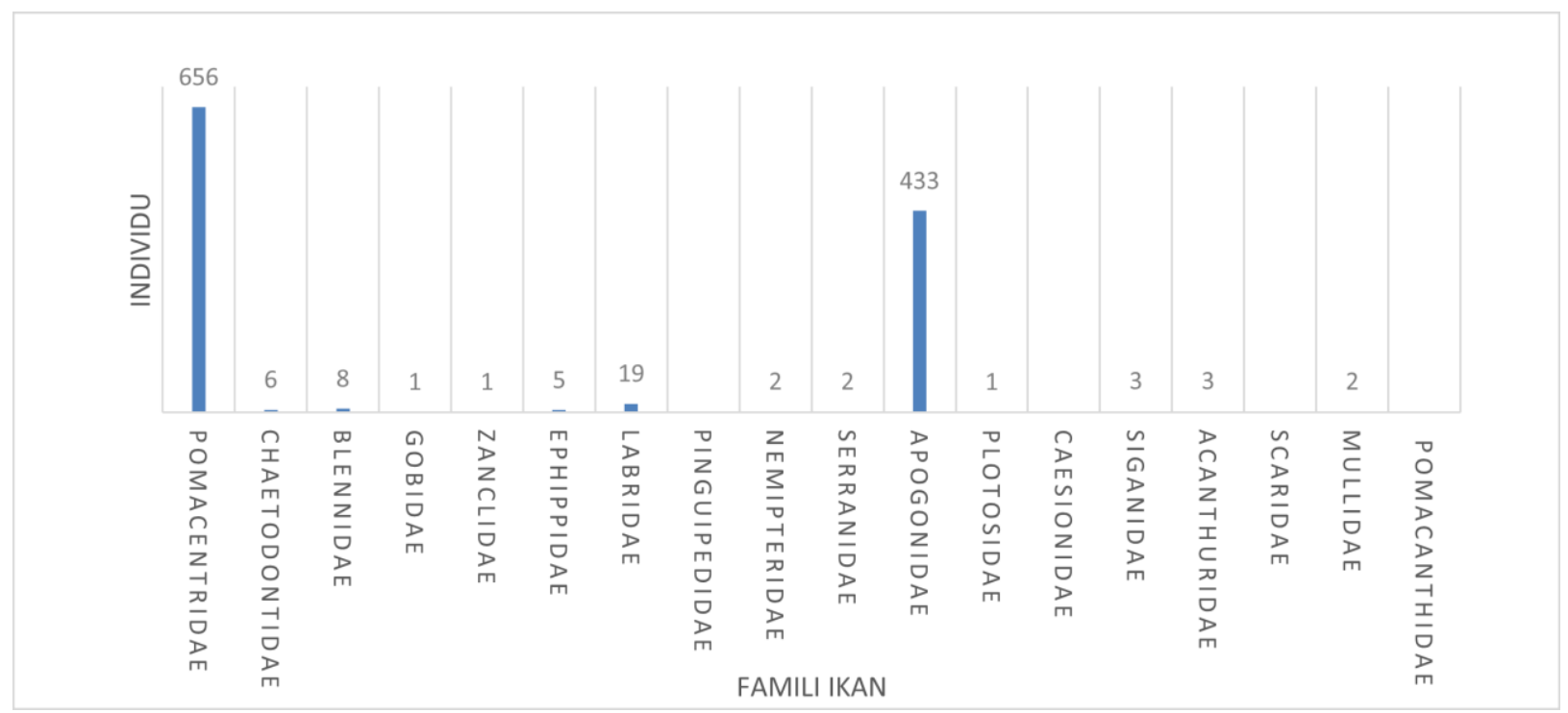

Gambar 4. Komposisi Jenis Ikan struktur Biorock Besar

medium 121.36 individu/ $/ \mathrm{m}^{2}$, struktutur Biorock medium 26.92 individu/ $\mathrm{m}^{2}$, struktutur Biorock kecil 15.52 individu $/ \mathrm{m}^{2}$, dan struktutur Biorock kecil 2 3.08 individu $/ \mathrm{m}^{2}$.

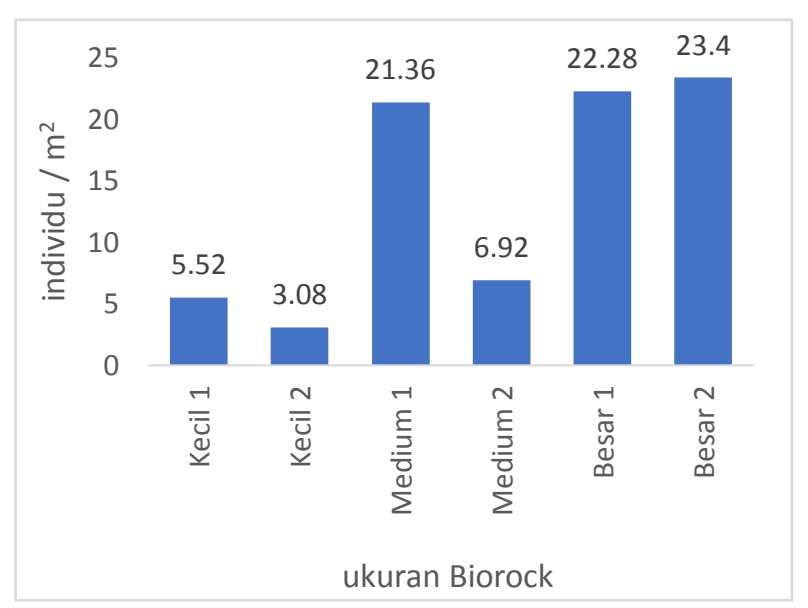

Gambar 5. Diagram Kelimpahan Ikan

Kelimpahan ikan sangat bervariasi, kelimpahan terendah terdapat pada struktur Biorock kecil 2 dengan kelimpahan sebesar 3.08 individu $/ \mathrm{m}^{2}$ dan kelimpahan tertinggi terdapat pada struktur
Biorock Besar 2 dengan kelimpahan sebesar 23.4 individu $/ \mathrm{m}^{2}$. Hal ini diduga pengaruh dari besar dan luasan struktur Biorock sebagai habitat dari ikan. Seperti pada struktur Biorock medium 1 sebesar 21.36 individu $/ \mathrm{m}^{2}$ dan struktur Biorock medium 2 sebesar 6.92 individu $/ \mathrm{m}^{2}$. Pada struktur Biorock medium 1 memiliki dimensi panjangxlebar \pm $3 \mathrm{~m}: 3 \mathrm{~m}$, struktur ini memiliki rongga yang cukup luas dan ditutupi terumbu karang hidup sebesar $69 \%$. Bentuk pertumbuhan karang pada struktur Biorock medium 1 sebagian besar adalah Acropora dan Coral Branching sehingga dijadikan sebagai tempat mencari makan dan berlindung bagi ikan ikan. Dimana kelimpahan ikan terbanyak adalah dari famili Pomacentridae.

Hal ini senada dengan pernyataan Rondonuwu dkk. (2013) yang menyatakan bahwa ikan famili Pomeacentridae berada di sekitar karang untuk berlindung dari ikan karnivora. sedangkan pada struktur Biorock medium 2 berdimensi panjangxlebar $\pm 3.5 \mathrm{~m}: 3 \mathrm{~m}$ memiliki rongga yang tidak terlalu luas dan terdapat banyak karang mati di dalamnya sehingga ikan jarang ditemukan pada lokasi ini.

Tabel 3.

Struktur Komunitas Ikan

\begin{tabular}{lcccccc}
\hline \multicolumn{1}{c}{\begin{tabular}{c} 
Struktur Komunitas Ikan \\
\multicolumn{1}{c}{ Karang }
\end{tabular}} & Kecil 1 & Kecil 2 & Medium 1 & Medium 2 & Besar 1 & Besar 2 \\
\cline { 2 - 7 } & 1.75 & 2.01 & 1.57 & 2.11 & 1.58 & 2.95 \\
\hline Indeks Keanekaragaman (H') & 0.70 & 0.81 & 0.55 & 0.71 & 0.62 & 0.95 \\
Indeks Keseragaman (E) & 0.22 & 0.17 & 0.30 & 0.18 & 0.28 & 0.15 \\
Indeks Dominasi ( C) & & &
\end{tabular}


Karang hidup yang terdapat pada struktur Biorock medium 2 hanay sebesar $50 \%$. Dilihat dari jenis ikan karang yang ditemukan mayoritas ikan adalah pemakan alga, plankton, invertebrata bentik, dan moluska. Famili Pomacentridae, Chaetodontidae, Gobidae, Labridae, dan seranidae merupakan jenis yang paling banyak dijumpai hampir diseluruh ukuran Biorock, hal ini kemungkinan berhubungan dengan kebiasaan makan dari dari ikan jenis ini yaitu pemakan alga, moluska, krustacea, dan zooplantonk. Tutupan alga pada struktur Biorock diduga sebagai penyebab kemunculan dari famili tersebut.

\subsection{Struktur Komunitas Ikan}

Struktur komunitas ikan dapat dilihat dari indeks keanekaragaman $\left(\mathrm{H}^{\prime}\right)$, indeks keseragaman $(\mathrm{E})$, dan indeks dominasi (C) yang tersedia pada Tabel 3, indeks keanekaragaman adalah ukuran kekayaan komunitas dilihat dari jumlah spesies dalam suatu kawasan, beserta jumlah individu dalam tiap spesies.

Indeks keanekaragaman $\left(\mathrm{H}^{\prime}\right)$ pada setaip Biorock memiliki nilai yang berbeda - beda pada setiap ukuran. Sesuai dengan klasifikasi indeks keanekaragaman Shannon - wiener semua ukuran Biorock yang menjadi objek penelitian memiliki kisaran nilai 1.57 - 2.95. Nilai Indeks keseragaman menunjukkan bahwa pada setiap ukuran Biorock termasuk dalam kategori keanekaragaman sedangmm $\left(1<\mathrm{H}^{\prime} \leq 3\right)$ yang dapat diartikan bahwa kestabilan komunitas pada struktur Biorock dalam kondisi normal. Struktur Biorock yang memiliki nilai indeks keanekaragaman terendah terdapat pada ukuran Medium 1 dan indeks keanekaragaman tertinggi terdapat pada ukuran Besar 2.

Indeks Keseragaman (E) dapat dijadikan sebagai indikator ada tidaknya pendominasian oleh jenis ikan tertentu pada suatu komunitas. Nilai indeks keseragaman pada struktur Biorock berkisar dari $0.55-0.95$. Nilai indeks menunjukkan bahwa nilai mendekat 1,0 yang berarti keseragaman komunitas tinggi dan tidak terjadi pendominasian oleh jenis tertentu. Struktur Biorock medium 1 memiliki nilai indeks kerseragaman terendah dibandingkan dengan ukuran struktur Biorock yang lain.

Dari hasil perhitungan indeks dominasi (C) didapatkan nilai yang berkisar dari $0.15-0.30$ yang termasuk dalam kategori rendah. Dimana pada setiap ukuran Biorock tidak terjadi pendominasian oleh satu spesies. Struktur Biorock medium 1 memiliki nilai indeks dominasi tertinggi dibandingkang struktur Biorock yang lain. Dilihat dari semua semua data indeks keanekaragaman, indeks keseragaman, dan indeks dominasi menunjukkan bahwa struktur Biorock medium 1 terjadi sedikit pendominasian oleh jenis tertentu akan tetapi nilainya masih dianggap kecil. Sehingga dapat diambil kesimpulan bahwa semua ukuran struktur Biorock memiliki struktur komunitas dalam kondisi yang stabil. Menurut Young et al. (2012), tinggi rendahnya keanekaragaman jenis ikan dipengaruhi oleh banyak faktor, salah satunya adalah kualitas lingkungan. Selain itu menurut Wahyudewantoro dkk. (2014) keanekaragaman ikan erat kaitannya dengan substrat dan kelimpahan ikan berkaitan dengan tingkat kesuburan perairan.

\subsection{Tutupan Karang}

Tutupan karang keras pada struktur Biorock dibedakan menjadi 3 ukuran, yaitu ukuran kecil (Kecil), sedang (Medium) dan besar (Besar). Masingmasing ukuran diambil 2 sampel struktur Biorock. Gambar 6 sampai 11 menyajikan secara lengkap persen tutupan karang pada masing-masing ukuran struktur Biorock.

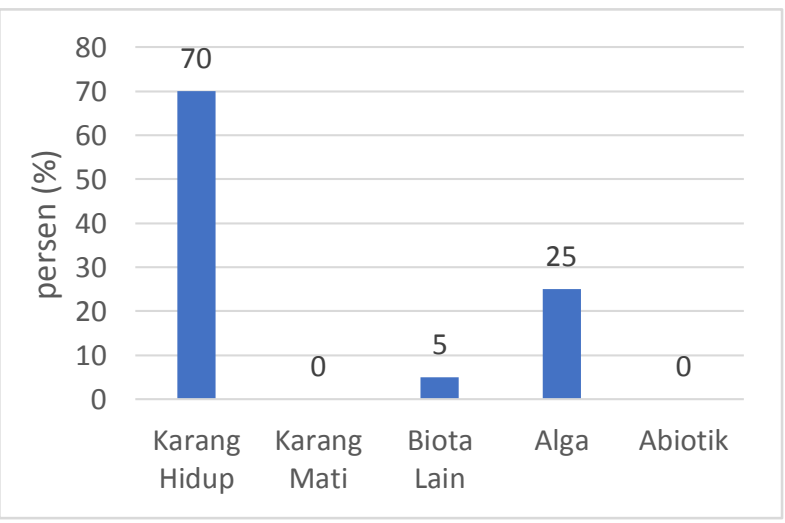

Gambar 6. Tutupan karang pada Biorock Kecil 1

Dari Gambar 6 diketahui bahwa kondisi karang pada struktur Biorock ukuran kecil 1 memiliki persentase karang hidup sebesar $70 \%$ yang berarti karang dalam kondisi yang baik. Pada titik ini tutupan karang hidup didominasi oleh Acropora Branching sebesar 27,5\%, Coral Encrusting sebesar 10,83\%, Coral Foliose sebesar 28,33\% dan Coral Mushroon sebesar 3,33\%. Selain itu juga terdapat Turf Algae sebesar 25\% dan Sponges sebesar 5\%. 
Sementara itu, dari Gambar 7 dapat diketahui bahwa tutupan karang hidup sebesar 65\% yang berarti karang dalam kondisi baik. Tutupan karang hidup pada titik ini didominasi oleh Acropora Branching sebesar $44.44 \%$, Coral Branching sebesar 15,48\% dan Coral Encrusting sebesar 4,76\%. Selain itu struktur Biorock ini dipenuhi Turf Algae sebesar $34,92 \%$.

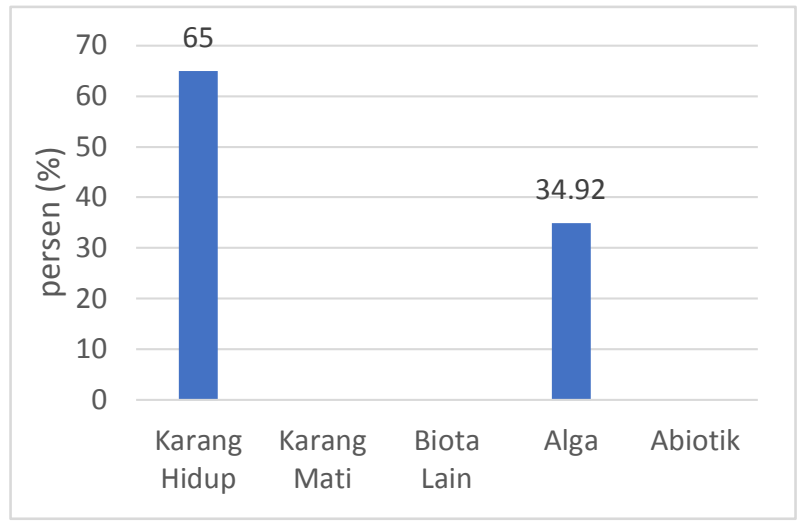

Gambar 7. Tutupan karang pada Biorock Kecil 2

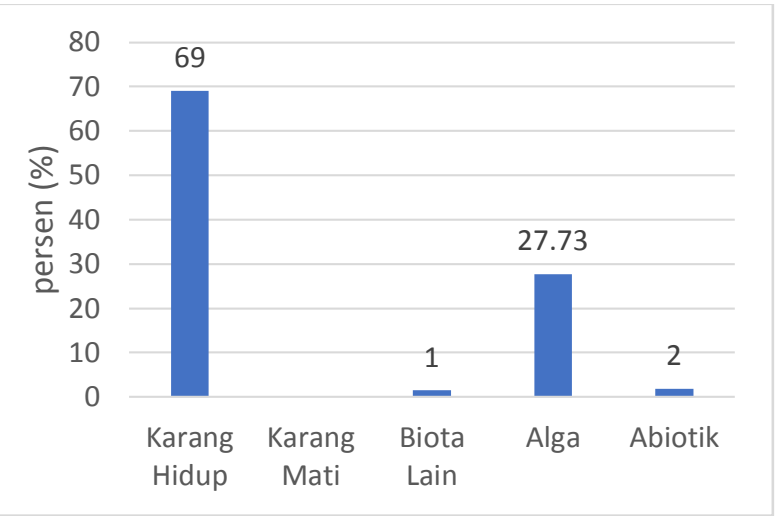

Gambar 8. Tutupan karang pada Biorock Medium 1

Berdasarkan Gambar 8 diketahui bahwa tutupan karang hidup sebesar $69 \%$ yang berarti karang dalam kondisi baik. Tutupan karang hidup pada titik ini didominasi oleh Acropora Branching sebesar 11,82\%, Acropora Tabulate sebesar 6,36\%, Coral Branching sebesar 0,82\%, Coral Encrusting sebesar 24,55\%, Coral Foliose sebesar 14,55\% dan Coral Massive sebesar 9,09\%. Biota lain berupa Soft Coral sebesar 0,55\% dan Sponges sebesar 0,91\% selain itu juga terdapat Turf Algae sebesar 27,73\%. Ukuran Struktur Biorock mempengaruhi jumlah bentuk pertumbuhan yang ada pada Strukturnya, semakin besar struktur terlihat bentuk pertumbuhan karang juga lebih bervariasi.

Dari Gambar 9 diketahui bahwa tutupan karang hidup sebesar 50\% yang berarti karang dalam kondisi baik. Tutupan karang hidup pada titik ini didominasi oleh Acropora Branching sebesar 17,55\%, Acropora Tabulate sebesar 5,30\%, Coral Branching sebesar 6,09\%, Coral Encrusting sebesar 3,3\%, Coral Massive sebesar 5,43\%, dan Coral Submassive sebesar $12.45 \%$. Sedangkan untuk Turf Algae sebesar sendiri sebesar 34,64\%, Rubble sebesar 0,99\%, Biota lain berupa Soft Coral sebesar 2,32\% dan Sponges sebesar 3,31\%

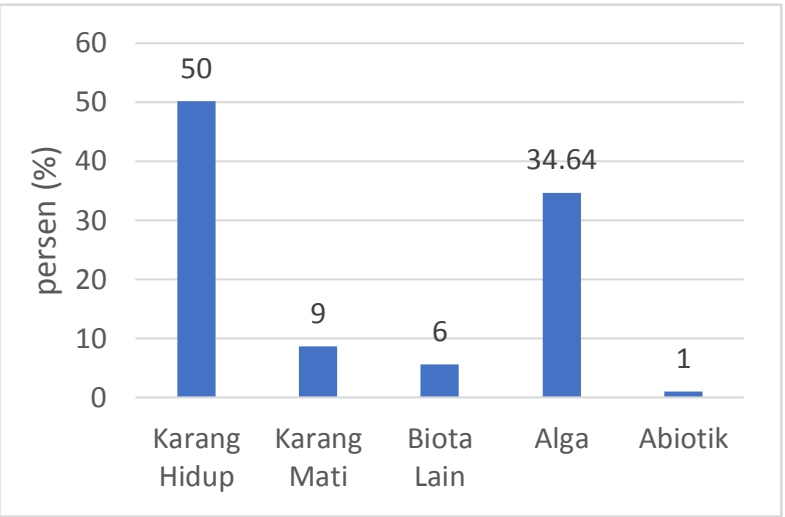

Gambar 9. Tutupan karang pada Biorock ukuran Medium 2

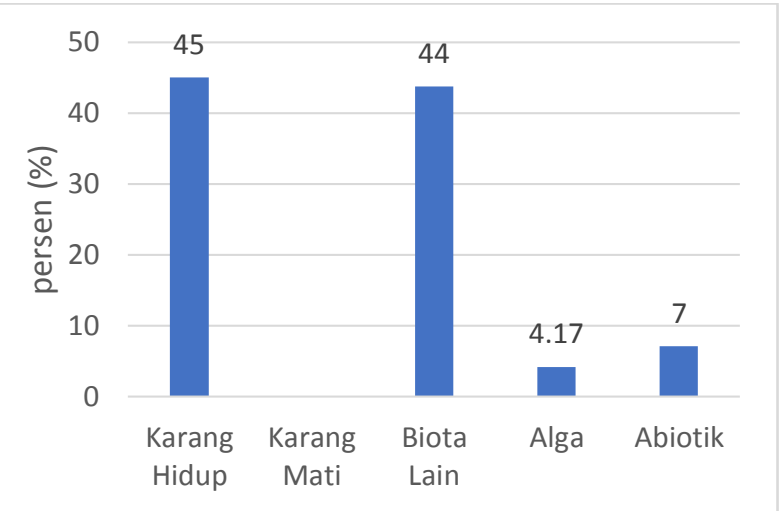

Gambar 10. Tutupan karang pada Biorock Besar 1

Dari Gambar 10 diketahui bahwa tutupan karang hidup sebesar $45 \%$ yang berarti dalam kondisi sedang, letak struktur Biorock titik ini pun sangat berdekatan dengan substrat pasir berlumpur yang dapat mengganggu proses pertumbuhan karang sendiri. Pada titik ini tutupan karang hidup didominasi oleh Acropora Digitate sebesar 2,92\%, Coral Branching sebesar 15,83\%, Coral Encrusting sebesar 5,00\%, Coral Foliose sebesar 10,00\%, Coral Massive sebesar $11,25 \%$. Biota lain pada titik ini didominasi oleh Soft Coral sebesar 14,58\% dan Sponges sebesar $29,17 \%$. Turf Algae sebesar 4,17\% dan Sand sebesar $7,08 \%$. 
Dari diagram diatas diketahui bahwa tutupan karang hidup pada titik L.2 dalam kondisi yang dengan persentase sebesar $68 \%$ yang didominasi oleh Acropora Branching sebesar 25,00\%, Coral Branching sebesar 15,38\%, Coral Encrusting sebesar 3,85\%, Coral Massive sebesar 20,19\%, Coral Submassive sebesar 3,85\%. Biota lain pada titik ini terdiri dari Sponges sebesar 12,50\%. Dan tutupan Turf Algae sendiri sebesar $19.23 \%$.

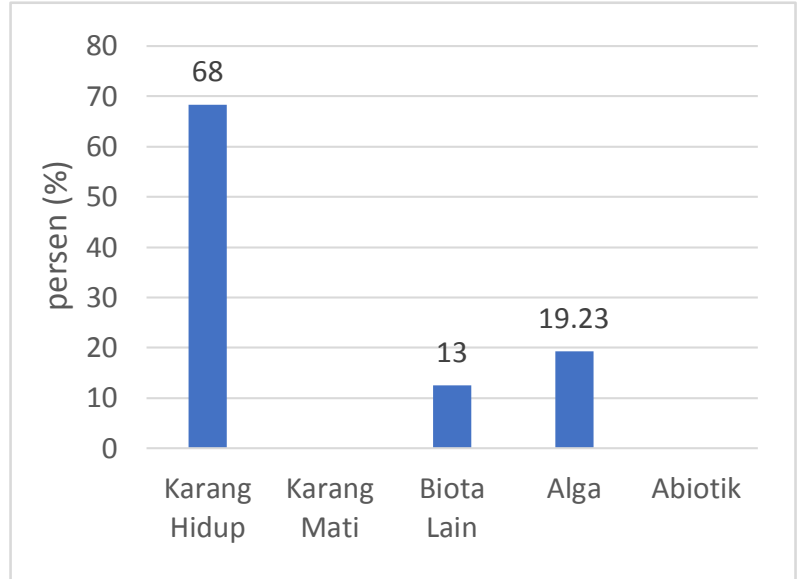

Gambar 11. Tutupan karang pada Biorock Besar 2

Semua ukuran Biorock memiliki nilai yang mengindikasinkan bahwa karang dalam kondisi yang baik. Tutupan karang tertinggi secara berurutan terdapat pada struktur Biorock berukuran Kecil 1, medium 1, Besar 2, Kecil 2, medium 2, Besar 1. Struktur Biorock Kecil 1 memiliki tutupan karang hidup sebesar $70 \%$ dengan tutupan alga $25 \%$ sedangkan pada struktur Biorock Besar 1 tutupan karang hidup hanya sebesar $45 \%$ dengan tutupan biota lain berupa soft coral sebesar $44 \%$, hal ini diduga sebagai persaingan tempat hidup antara karang hidup dan soft coral sehingga karang hidup yang ditemukan pada struktur Biorock pada ukuran ini memiliki nilai yang terendah daripada ukuran struktutr Biorock yang lain.

Selain dari tutupan biota lain yang ditemukan pada struktur Biorock. Tutupan alga juga memiliki nilai yang relative besar dengan kisaran $4.17 \%$ $34.92 \%$. Karang hidup pada struktur Biorock selain bersaing dengan biota lain juga bersaing dengan alga untuk mendapatkan substrat tempat mereka hidup. Dari data yang didapatkan menunjukkan bahwa pada struktur Biorock banyak dijumpai karang dengan bentuk pertumbuhan bercang. Selain pertumbuhannya yang cepat karang ini sangat rentan dan mudah patah apabila terdapat arus yang kuat di perairan tempat mereka tumbuh. Menurut Prasetya (2014) arus yang kuat dapat mematahkan cabang - cabang karang.

\subsection{Indeks Mortalitas Terumbu Karang}

Indeks mortalitas pada semua ukuran struktutur Biorock menunjukkan nilai 0, kecuali pada struktutr Biorock medium 2 yaitu 0.14 (Gambar 12). Nilai ini juga menunjukkan bahwa indeks mortalitas terumbu karang yang berada pada struktur Biorock sangatlah kecil. Sehingga dapat disimpulkan bahwa angka kematian karang kecil dan karang dalam kondisi baik. Berikut gambar indeks mortalitas pada semua ukuran.

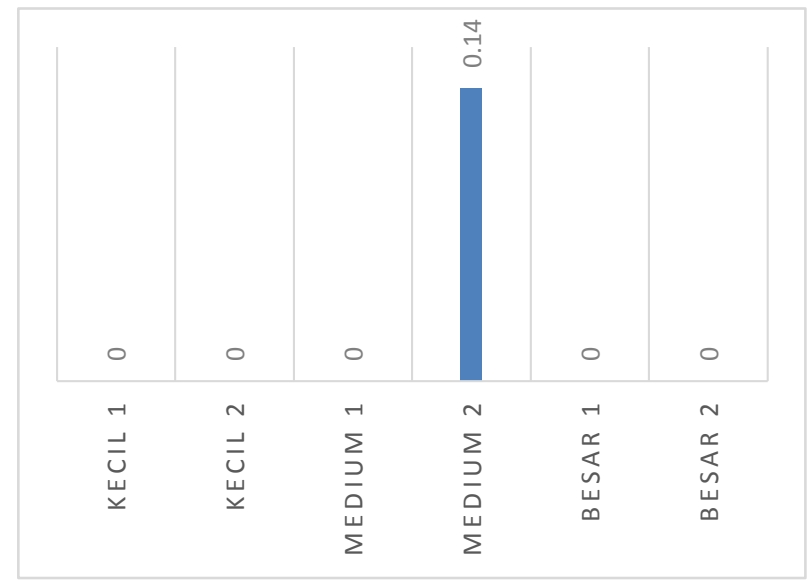

Gambar 12. Indeks Mortalitas Terumbu Karang

Berdasarkan pada gambar 16 dapat dilihat bahwa tingkat kematian karang pada struktur Biorock memiliki nilai yang rendah dengan kisaran nilai 0 - 0.14. Rendahnya nilai dari Indeks Mortalitas Karang menunjukkan bahwa struktur Biorock merupakan tempat yang cocok untuk pertumbuhan dan perkembangan karang. Tingkat kematian karang yang rendah dapat mengindikasin bahwa kondisi terumbu karang dalam keadaan yang baik. Rekruitmen karang juga dapat terjadi di struktur Biorock dan akan tumbuh dan berkembang dalam kondisi yang baik, Karena nilai indeks mortalitas karang yang kecil.

\subsection{Indeks Kesamaan Bray-Curtis}

Dari gambar dendogram (Gambar 13) menunjukkan bahwa struktur Biorock yang memiliki kesamaan terdekat adalah Medium 2 dengan Kecil 1. Struktutr Biorock Kecil 2 memiliki kesamaan terdekat dengan medium 2 dan Kecil 1. Struktur Biorock Besar 2 memiliki kesamaan dengan 
medium 1. Sedangkan struktur Biorock Besar 1 merupakan struktur yang paling jauh memiliki nilai kesamaan dengan struktur Biorock lainnya.

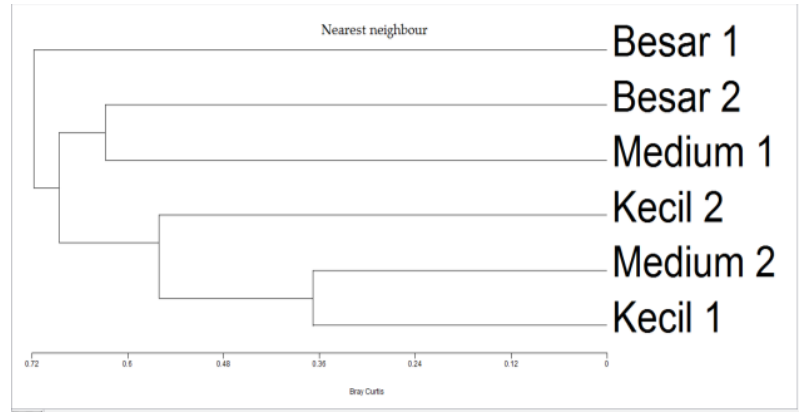

Gambar 13. Dendogram Kesamaan Jenis Struktur Biorock

Indeks Bray - Curtis merupakan Indeks yang digunakan untuk melihat tingkat kesamaan antar stasiun (ukuran struktur Biorock). Dari gambar dendogram tersebut diketahui bahwa terdapat 3 kelompok yang menunjukkan kesamaan yang terdekat. Kelompok pertama yaitu struktur Biorock Kecil 1, Medium 2, dan Kecil 2. Kelompok kedua yaitu struktur Biorock Besar 2 dan Medium 1. Kedua kelompok ini memiliki kesamaan yang realtif dekat. Hal ini disebabkan oleh kesamaan spesies yang muncul pada struktur Biorock. Sedangkan struktur Biorock Besar 1 merupakan kelompok ketiga yang memiliki nilai kesamaan terendah dibandingkan struktutr Biorock yang lain

\section{Simpulan}

Dari penelitian yang sudah dilakukan dapat disimpulkan bahwa struktur komunitas ikan di Biorock ditemukan 18 Famili dan 45 Spesies dan kelimpahan total ikan 2065 individu. Dengan rincian terumbu buatan Biorock ukuran Kecil 1 terdiri dari 6 famili dan 12 spesies; Kecil 2 terdiri dari 8 famili dan 12 spesies; Medium 1 terdiri dari 11 famili 11 spesies; Medium 2 terdiri dari 12 famili dan 20 spesies; Besar 1 terdiri dari 8 famili dan 13 spesies; dan Besar 2 terdiri dari 11 famili dan 22 spesies. Indeks keanekaragaman, indeks keseragaman dan indeks dominasi pada semua terumbu buatan Biorock menunjukkan dalam kondisi yang stabil tidak ada pendominasian oleh individu tertentu.

Tutupan karang pada terumbu buatan Biorock secara keseluruhan dalam kondisi baik selain pada terumbu buatan Biorock ukuran Besar 1 yang tergolong dalam kondisi sedang. Tutupan karang hidup pada Biorock Kecil 1 sebesar 70\%, Biorock Kecil 2 sebesar 65\%, Biorock Medium 1 sebesar 69\%, Biorock Medium 2 sebesar 50\%, Biorock Besar 1 sebesar $45 \%$, dan Biorock Besar 2 sebesar 68\% . Jenis pertumbuhan karang yang mendominasi pada terumbu buatan Biorock adalah Acropora branching.

\section{Ucapan terimakasih}

Terimakasih penulis ucapkan kepada Dinas Perikanan dan Kelautan Kabupaten Buleleng, Yayasan Reef Check Indonesia, Coral Alliance Indonesia, Kelompok Masyarakat Karang Lestari.

\section{Daftar Pustaka}

Bottema, M. J., \& Bush, S. R. (2012). The durability of private sector-led marine conservation: A case study of two entrepreneurial marine protected areas in Indonesia. Ocean \& coastal management, 61, 38-48.

Carpenter, K. E., Abrar, M., Aeby, G., Aronson, R. B., Banks, S., Bruckner, A., Chiriboga, A., Cortes, J., Delbeek, J. C., DeVantier, L., Edgar, G. J., Edwards, A. J., Fenner, D., Guzmán, H. M., Hoeksema, B. W., Hodgson, G., Johan, O., Licuanan, W .Y., Livingstone, S. R., Lovell, E. R., Moore, J. A., Obura, D. O., Ochavillo, D., Polidoro, B. A., Precht, W. F., Quibilan, M. C., Reboton, C., Richards, Z. T., Rogers, A. D., Sanciangco, J., Sheppard, A., Sheppard, C., Smith, J., Stuart, S., Turak, E., Veron, John E. N. J. E. N., Wallace, C., Weil, E., Wood, E., \& Wood, E. (2008). One-third of reef-building corals face elevated extinction risk from climate change and local impacts. Science, 321(5888), 560-563.

Dunning, K. H. (2015). Ecosystem services and community based coral reef management institutions in post blast-fishing Indonesia. Ecosystem Services, 16, 319-332.

Gomez, E. D., \& Yap, H. T. (1988). Monitoring reef condition. In Kenchington, R. A., \& Hudson, B. E. T. (Eds.). Coral Reef Management Handbook. Jakarta, Indonesia: UNESCO Regional office of Science and Technology for South-East Asia, pp. 187-195.

Harris, L. E. (2009). Artificial reefs for ecosystem restoration and coastal erosion protection with aquaculture and recreational amenities. Reef Journal, 1(1), 235-246.

Lissa. (2013). Keanekaragaman Ikan Karang di Terumbu Karang Kawasan Konservasi Pulau Biawak. Wacana Didaktita, 3(13), 47-50.

McLeod, E., Moffitt, R., Timmermann, A., Salm, R., Menviel, L., Palmer, M. J., Selig, E.R.,. Casey, K.S., \& Bruno, J. F. (2010). Warming seas in the Coral Triangle: coral reef vulnerability and management implications. Coastal Management, 38(5), 518-539. 
Odum, E. P. (1998). Dasar-dasar Ecology. Diterjemahkan oleh T. Samingan. Edisi Ketiga. Yogyakarta, Indonesia: Universitas Gajah Mada.

Prasetya, S. H., Munasik, \& Ambariyanto. (2014). Estimasi daya dukung terumbu karang berdasarkan biomassa ikan karang di Perairan Misool Selatan, Raja Ampat, Papua Barat. Journal of Marine Research, 3(3), 233-243.

Rondonuwu A.B., Tombokan J. L., \& Rembet U. N. W. J. (2013). Distribusi dan kelimpahan ikan karang famili pomacentridae di perairan terumbu karang Desa Poopoh Kecamatan Tombariri Kabupaten Minahasa. Jurnal Ilmiah Platax, 1(2), 87-91.

Somerfield, P. J. (2008). Identification of the Bray-Curtis similarity index: Comment on Yoshioka (2008). Marine Ecology Progress Series, 372, 303-306.
Sugianti, Y., \& Mujiyanto, M. (2016). Biodiversitas ikan karang di Perairan Taman Nasional Karimunjawa, Jepara. BAWAL Widya Riset Perikanan Tangkap, 5(1), 23-31.

Veron, J. E. N., Devantier, L. M., Turak, E., Green, A. L., Kininmonth, S., Stafford-Smith, M., \& Peterson, N. (2009). Delineating the coral triangle. Galaxea, Journal of Coral Reef Studies, 11(2), 91-100.

Wahyudewantoro G., Kamal M. M., Affandie R., \& Mulyadi. (2014). Jenis-Jenis Ikan Di Perairan Mangrove Suaka Margasatwa Muara Angke, Jakarta Utara. Zoo Indonesia, 23(2), 75-83

Young, C. N., Schopmeyer, S. A., \& Lirman, D. (2012). A review of reef restoration and coral propagation using the threatened genus Acropora in the Caribbean and Western Atlantic. Bulletin of Marine Science, 88(4), 1075-1098.

(C) 2017 by the authors; licensee Udayana University, Indonesia. This article is an open access article distributed under the terms and conditions of the Creative Commons Attribution license (http://creativecommons.org/licenses/by/3.0/). 